\title{
Silencing of Two Insulin Receptor Genes Disrupts Nymph-Adult Transition of Alate Brown Citrus Aphid
}

\author{
Bi-Yue Ding ${ }^{1,+}$, Feng Shang ${ }^{1,+}{ }^{+}$, Qiang Zhang ${ }^{1}$, Ying Xiong ${ }^{1}$, Qun Yang ${ }^{1}$, Jin-Zhi Niu ${ }^{1}$, \\ Guy Smagghe ${ }^{1,2}$ and Jin-Jun Wang ${ }^{1, *}$ \\ 1 Key Laboratory of Entomology and Pest Control Engineering, College of Plant Protection, \\ Southwest University, Chongqing 400715, China; biyueding@163.com (B.-Y.D.); \\ fengshang1994@yahoo.com (F.S.); qiangzhang1996@163.com (Q.Z.); yingxiong333@163.com (Y.X.); \\ qunyang1023@163.com (Q.Y.); jinzhiniu@swu.edu.cn (J.-Z.N.); guy.smagghe@ugent.be (G.S.) \\ 2 Department of Crop Protection, Ghent University, 9000 Ghent, Belgium \\ * Correspondence: wangjinjun@swu.edu.cn; Tel.: +86-23-6825-0255; Fax: +86-23-6825-1269 \\ + These authors contributed equally to this work.
}

Academic Editor: T. G. Emyr Davies

Received: 3 January 2017; Accepted: 2 February 2017; Published: 21 February 2017

\begin{abstract}
Insulin receptors play key roles in growth, development, and polymorphism in insects. Here, we report two insulin receptor genes (AcInR1 and AcInR2) from the brown citrus aphid, Aphis (Toxoptera) citricidus. Transcriptional analyses showed that AcInR1 increased during the nymph-adult transition in alate aphids, while $A c I n R 2$ had the highest expression level in second instar nymphs. AcInR1 is important in aphid development from fourth instar nymphs to adults as verified by dsRNA feeding mediated RNAi. The silencing of AcInR1 or/and AcInR2 produced a variety of phenotypes including adults with normal wings, malformed wings, under-developed wings, and aphids failing to develop beyond the nymphal stages. Silencing of AcInR1 or AcInR2 alone, and co-silencing of both genes, resulted in $73 \%$ or $60 \%$, and $87 \%$ of aphids with problems in the transition from nymph to normal adult. The co-silencing of AcInR1 and AcInR2 resulted in $62 \%$ dead nymphs, but no mortality occurred by silencing of $A c \operatorname{In} R 1$ or $A c \operatorname{In} R 2$ alone. Phenotypes of adults in the dsInR1 and ds $\operatorname{In} R 2$ were similar. The results demonstrate that $A \operatorname{In} R 1$ and $A c \operatorname{In} R 2$ are essential for successful nymph-adult transition in alate aphids and show that RNAi methods may be useful for the management of this pest.
\end{abstract}

Keywords: Aphis (Toxoptera) citricidus; insulin receptor genes; RNAi; development

\section{Introduction}

Insulin and insulin-like factor signaling (IIS) pathways play important roles in insects such as in body size [1], embryo development [2,3], diapause [4,5], and wing dimorphism [6]. Insulin receptor (InR) is the upstream component of the IIS pathway. InR is a transmembrane receptor that triggers the signal transduction cascade on insulin binding [7]. InR signal transduction primarily passes through the phosphoinositide 3-kinase (PI3K)/protein kinase B (Akt/PKB) pathway [8]. In the $\mathrm{PI} 3 \mathrm{~K} /$ Akt pathway, InR transmits a signal by the insulin receptor substrate (IRS), resulting in the activation of PI3K. PI3K catalyzes the phosphorylation of phosphatidylinositol-4,5-bisphosphate to phosphatidylinositol-3,4,5-trisphosphate (PIP3). Increased levels of PIP3 are required to activate phosphoinositide-dependent kinase, which in turn activates Akt, resulting in the phosphorylation of many other proteins that affect cell cycle entry, growth and survival [3,9]. In addition to the PI3K/PKB signaling cascade, the target of the rapamycin complex and the Ras/mitogen-activated protein kinase signaling pathways constitute two alternative signaling branches of the IIS pathway [6,10-12]. 
Two types of insect InR receptors, InR1 and InR2, have been identified. In some insects, only one insulin receptor gene occurs. These insects include the Diptera: Drosophila melanogaster [13], Bactrocera dorsalis [3], and Aedes aegypti [14]; Lepidoptera: Bombyx mori [15], Blattoidea: Blattella germanica [16]; and Coleoptera: Onthophagus nigriventris [17]. Both insulin receptor genes have been identified in polymorphic insects, such as Aphis mellifera [18], Solenopsis invicta [19], Nilaparvata lugens [6], Acyrthosiphon pisum [2], and the non-polymorphic insect Tribolium castaneum [7]. RNA interference (RNAi) methods have been used to investigate the function of insulin receptor genes involved in insect growth [20,21], development and reproduction [7,22], polymorphism [6], and lifespan [23]. For example, the ds $\operatorname{In} R$-treated individuals of B. mori showed growth inhibition and malformation such as abnormal black body color [22]. In insects with two insulin receptor genes, such as T. castaneum, functional diversity occurs. RNAi results in T. castaneum indicated that InR1 and InR2 have different functions in beetle development and reproduction [7]. Similar functions were also found in N. lugens with InR1 and InR2 playing opposing roles in controlling the development of the long wing biotype versus the short wing biotype [6].

Aphids are good examples of taxa that have evolved wing dimorphism and reproductive polyphenism $[24,25]$. Generally, all aphids are born with wing primordia but apterous (wingless) and alate (winged) aphids cannot be distinguished by examining the morphology of first and second instar nymphs [26]. The primordia are degenerating during the second instar nymph-third instar nymph in apterous morphs [27]. In alate morphs, the wing bud develops slowly in each nymphal stadium until the fully formed wing unfolds after the nymph-to-adult molt [26]. Besides wing dimorphism, aphids also have various reproductive modes. In general, offspring are produced by either viviparous parthenogenesis or sexual production. Nymphs undergo four molts during development to become alate or apterous adults $[28,29]$.

The brown citrus aphid, Aphis (Toxoptera) citricidus (Kirkaldy), is an important citrus pest and the main vector of citrus tristeza virus (CTV) worldwide. CTV is one of the most destructive and widely distributed diseases of citrus [30,31]. Like other aphid species, A. citricidus has alate and apterous morphs. Apterous morphs have high fecundity whereas alates have strong flight muscles and can fly long distances [32]. The life cycle of A. citricidus is simpler than that of most aphid species. In most regions, A. citricidus is permanently anholocyclic, meaning that there is no sexual cycle in the autumn. All individuals are viviparous parthenogenetic females year round [33]. The strong flight muscles and high fecundity of $A$. citricidus have made control using chemical insecticides difficult. Understanding the molecular regulation of the development process in alate morphs is needed to advance efficient control strategies.

Although the genomes of three species of aphids, including A. pisum [29], Diuraphis noxia [34], and Myzus persicae, have been sequenced, insulin receptor genes have only been characterized in A. pisum [2]. In this study, we report (1) two full-length open reading frame (ORF) sequences of the AcInR1 and AcInR2 insulin receptors in A. citricidus; (2) different expression patterns of AcInR1 and $A \operatorname{InR} 2$ at different aphid developmental stages; and (3) evidence for the involvement of $A c \operatorname{In} R 1$ and $A c I n R 2$ in the nymph-adult transition by using dsRNA feeding-mediated RNA interference (RNAi). This study can be useful to analyze the insulin receptors in other aphids. The results would support advanced studies using RNAi technology as a method to manage populations of $A$. citricidus.

\section{Results}

\subsection{Two Insulin Receptor Genes in A. citricidus}

We obtained the open reading frame (ORF) sequences of the AcInR1 and AcInR2 insulin receptor genes from A. citricidus. AcInR1 contained an ORF of 4473 bp that encoded 1490 amino acid residues (aa) with a predicted molecular weight of $169.7 \mathrm{kDa}$ and an isoelectric point (pI) of 5.83 (Figure S1), and AcInR2 contained an ORF of $3963 \mathrm{bp}$ that encoded 1320 aa with a predicted molecular weight of $150.1 \mathrm{kDa}$ and a $\mathrm{pI}$ of 5.85 (Figure S2). Although the nucleotide sequence identity was only 
43.7\% between AcInR1 and AcInR2, AcInR1 and AcInR2 shared highly similar domain architecture: a furin-like cysteine-rich (Fu) region, three fibronectin type 3 (FN3) domains, a single transmembrane (TM) region, a highly conserved tyrosine kinase domain (TyrKc), an "NPXY" motif, and a triple tyrosine cluster (YXXXYY) (Figures S1 and S2).

A Protein Blast (BLASTP) search of the National Center for Biotechnology Information (NCBI) databases (available on: http:/ /www.ncbi.nlm.nih.gov/) and the Aphid Genome Database (available on: http:/ /www.aphidbase.com/) found that the amino acid sequence of AcInR1 shared a similarity of 96\%, 95\%, and 94\% with MpInR1 (M. persicae), ApInR1 (A. pisum, XP_008185917.1), and DnInR1 (D. noxia, XP_015375915.1), whereas AcInR2 shared a 92\%, 90\%, and 90\% similarity with ApInR2 (A. pisum, XP_001942660.2), DnInR2 (D. noxia, XP_015375915.1), and MpInR2 (M. persicae), respectively.

To investigate the evolutionary relationship of insect insulin receptors, a phylogenetic analysis based on the full-length amino acid sequences was performed with orthologs from various insect species. InR1 and InR2 separated into two distinct clusters, which indicated that InR2 may play a different role than InR1. Further, InR and InR1 appeared to share a single clade, suggesting that similar physiological functions and evolutionary relatedness exist between InR and InR1 (Figure 1). All aphid insulin receptors seemed to have a common lineage as a high bootstrap value confirmed their phylogeny (Figure 1). InR2 presented in Hymenoptera (ant and bumble bee), Hemipteran (aphids, planthopper, and bugs), Isoptera (dampwood termite), and Coleoptera (red flour beetle) (Figure 1). However, not all species belonging to these groups have two insulin receptors. Only one insulin receptor was found in Nasonia vitripennis (Hymenoptera) and Onthophagus nigriventris (Coleoptera).

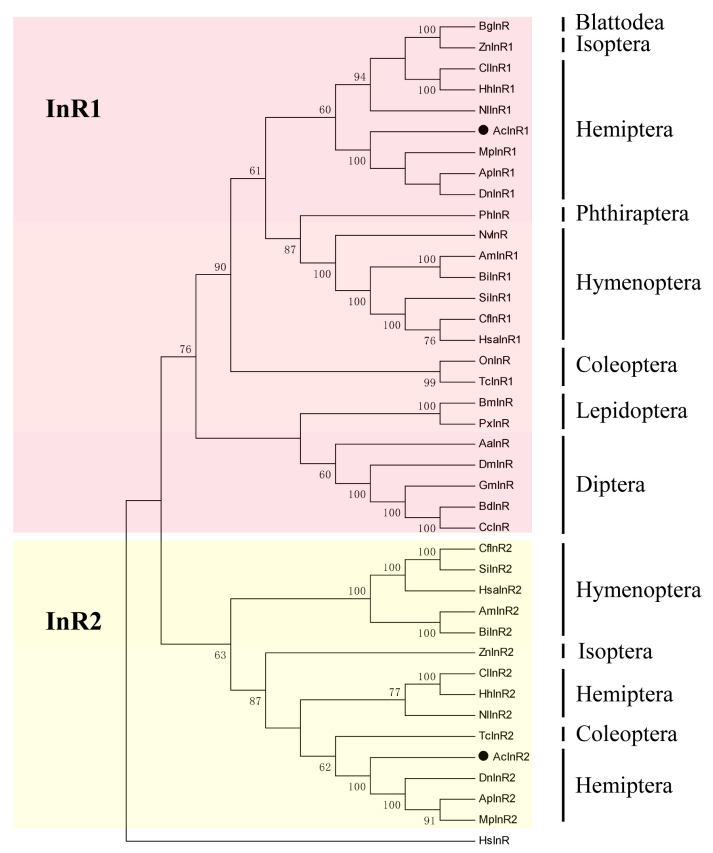

Figure 1. Phylogeny of insect insulin receptors. A phylogenetic tree constructed from amino acid sequences of various insect insulin receptors. The tree was constructed using MEGA 5.05 based on the maximum likelihood (ML) method according to amino acid sequences. Bootstrap support values with 1000 samples are shown on the branches (only those above 50\%). Insulin receptors were from Blattella germanica (Bg), Zootermopsis nevadensis (Zn), Climex lectularius (Cl), Halyomorpha halys (Hh), Nilaparvata lugens (Nl), Aphis (Toxoptera) citricidus (Ac), Myzus persicae (Mp), Acyrthosiphon pisum (Ap), Diuraphis noxia (Dn), Pediculus humanus corporis (Ph), Nasonia vitripennis (Nv), Apis mellifera (Am), Bombus impatiens (Bi), Solenopsis invicta (Si), Camponotus floridanus (Cf), Harpegnathos saltator (Hsa), Onthophague nigriventris (On), Tribolium castaneum (Tc), Bombyx mori (Bm), Plutella xylostella (Px), Aedes aegypti (Aa), Drosophila melanogaster (Dm), Glossina morsitans morsitans (Gm), Bactrocera dorsalis (Bd), Ceratitis capitata (Cc) Homo sapiens (Hs). 


\subsection{Expression Profiles of AcInR1 and AcInR2 at Different Developmental Stages}

We analyzed the expression patterns of AcInR1 and AcInR2 at different developmental stages of A. citricidus by quantitative real-time PCR (RT-qPCR). The results showed that $A \operatorname{In} R 1$ and $A \ln R 2$ were constantly expressed from the first instar nymph to the adult. However, AcInR1 increased from fourth instar nymphs to alate adults. There was no significant difference among the nymphal stages of alates and also no significant differences were observed among nymphal stages and adults in apterous aphids (Figure 2A). The results indicate that AcInR1 plays an important role in the development (including wing development) from fourth instar nymphs to alate adults.

AcInR2 had the highest expression level in second instar nymphs (about 3.4-fold higher than in first instar nymphs). No differences among third instar nymphs, fourth instar nymphs, and adults of alate aphids were observed. In apterous aphids, the expression of AcInR2 increased with nymphal growth between the third and fourth instars and then decreased in the adults. The expression level of $A c I n R 2$ was higher in apterous aphids compared to alate aphids in third and fourth instar nymphs as well as in adults (Figure 2B). The second instar nymph to third instar nymph was the key period for determining the wing morph (apterous or alate morph) and the fourth instar nymph to adult transition was the important period for wing development in aphids [35]. These results suggest that $A c \operatorname{In} R 2$ may be involved in wing dimorphism and AcInR1 may play a role in the wing development of $A$. citricidus.

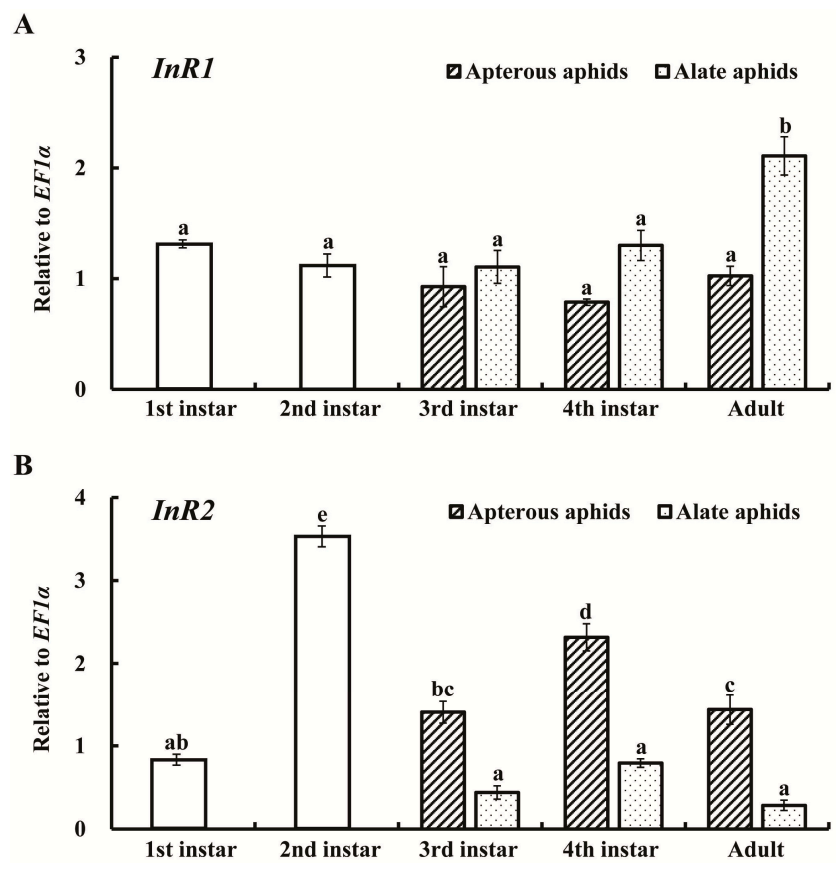

Figure 2. Expression profiles of $A \operatorname{cInR} 1$ (A); and $A c I n R 2$ (B) at different developmental stages of Aphis (Toxoptera) citricidus. The mean $( \pm \mathrm{SE})$ expression level is based on four biological replicates. Different lowercase letters (a, b, c, d, e) above each bar indicate significant differences among different developmental stages and wing morphs using one-way ANOVA followed by Tukey's honestly significant difference (HSD) multiple comparison test $(p<0.05)$.

\subsection{Silencing of AcInR1 and AcInR2 by RNAi Showed Clear Phenotypes}

Based on a previously developed method using a plant-stem-mediated dsRNA feeding system [36], the effective and specific silencing of AcInR1 and AcInR2 by RNAi was established in A. citricidus to further explore the role of these genes in the nymph-adult transition and wing formation. This approach first evaluated the individual silencing of AcInR1 or AcInR2 without influencing the expression of the other gene. We also used a mixture of dsRNA to target both AcInR1 and AcInR2 in order to evaluate the function of this pathway. 
Feeding of dsInR1 specifically silenced the expression of AcInR1 by $45 \%$ compared to the control, while the expression of $A c I n R 2$ was not changed (Figure 3A). Similar results were observed in the dsInR 2 treatment. The expression of $A c I n R 2$ was reduced by $54 \%$ compared to the control, while the expression level of AcInR1 was not changed (Figure 3B). When the aphids fed on the mixture of dsInR1 and dsInR2, the expression levels of $A \operatorname{In} R 1$ and $A \operatorname{In} R 2$ were significantly down-regulated by $64 \%$ and $72 \%$, respectively, compared to the control (Figure $3 C$ ).

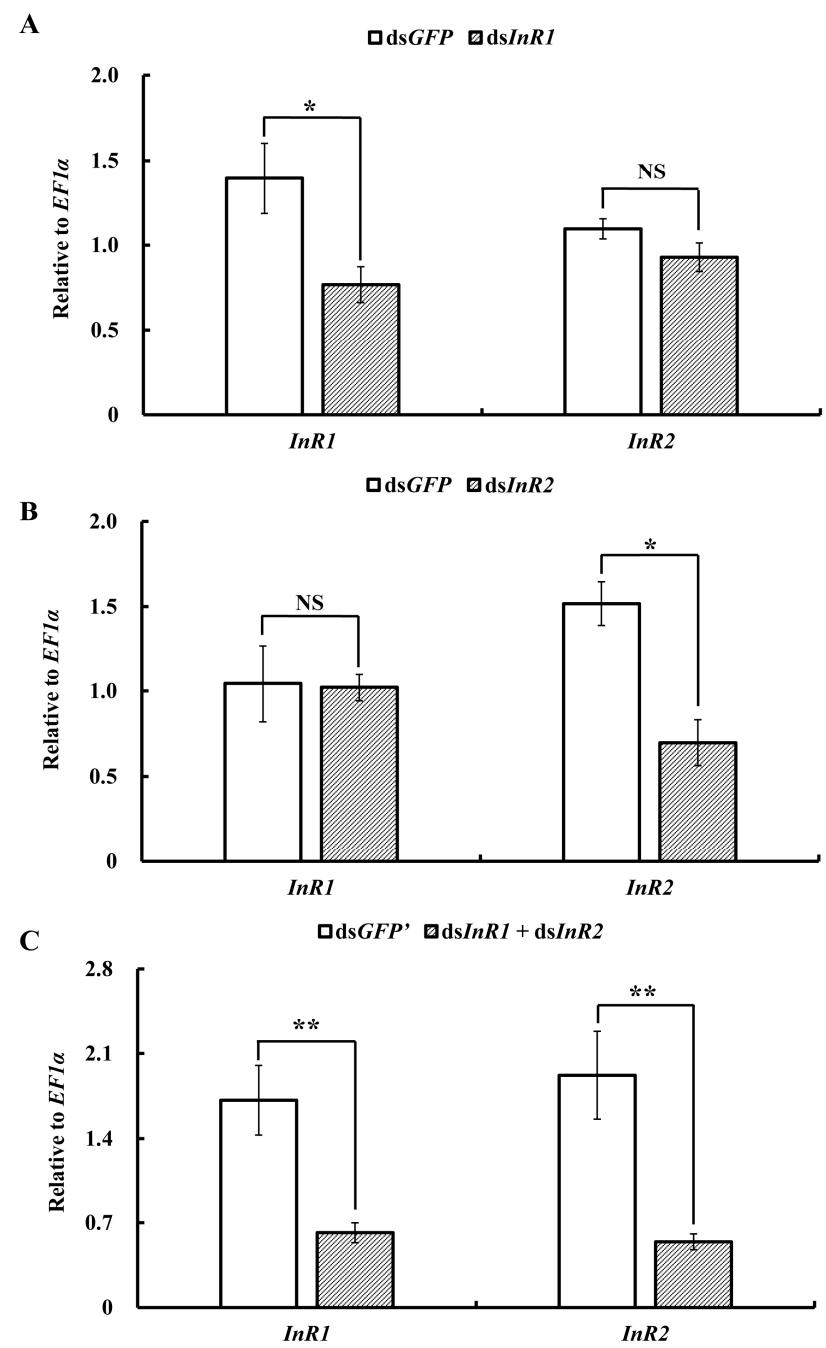

Figure 3. Relative expression levels of $A c \operatorname{In} R 1$ and $A c \operatorname{In} R 2$ after feeding on specific dsRNA. (A) Expression levels of AcInR1 and AcInR2 after feeding on dsInR1; (B) expression levels of AcInR1 and $A c I n R 2$ after feeding on dsInR2; (C) expression levels of AcInR1 and AcInR2 after feeding on a mixture of ds $\operatorname{In} R 1$ and ds $\operatorname{In} R 2$. The mean $( \pm \mathrm{SE})$ expression level is based on four biological replicates. Significant differences between treatment and control are indicated with a line with asterisks $\left({ }^{*} p<0.05\right.$; ** $p<0.01$, Student's $t$ test). "NS" indicates no significant difference between samples.

With effective silencing of $A c \operatorname{InR} 1$ or/and AcInR2 in fourth instar winged-nymphs (Figure 4A(a)) by dsRNA, we observed a variety of different phenotypes after treatment. These included adults with normal wings (Figure 4A(b)), adults with malformed wings (Figure 4A(c)), adults with under-developed wings (Figure $4 \mathrm{~A}(\mathrm{~d})$ ), aphids unable to molt out of the nymphal stage (live nymphs that would die at this stage in 2-3 days) (Figure 4A(e)), and dead nymphs (Figure 4A(f)). Fisher's exact tests of the percentage of the presented phenotypes among different treatments were performed in two ways: overall presented phenotypes and phenotypes separately. Silencing of AcInR1 resulted 
in $45 \%$ of the aphids trapped in the nymphal stage, while $55 \%$ could molt from nymph to adult including $27 \%$ with normal wings, $23 \%$ with malformed wings and $5 \%$ with under-developed wings. Among aphids treated with dsInR2, 36\% remained in the nymphal stage, $64 \%$ molted from nymphs to adults, including $40 \%$ with normal wings, $20 \%$ with malformed wings, and $4 \%$ with under-developed wings. In the control group, $100 \%$ of the aphids had normal wings. Aphids treated with the mixture of dsInR1 and dsInR2 were significantly different versus dsGFP in overall presented phenotypes $(p=0.000$, respectively) and within each phenotype (Table 1$)$. There was no significant difference between dsInR1 and dsInR2 treatments in all presented phenotypes $(p=0.292)$ as well as in the specific phenotypes (Table 1). Upon silencing of both InR1 and InR2, only $38 \%$ of the aphids molted from nymphs into adults, including $13 \%$ with normal wings and $25 \%$ with malformed wings, while the rest of treated aphids $(62 \%)$ died in the nymph stage. For aphids treated with dsGFP' (with the same dose of dsRNA as in the mixture of dsInR1 and ds $\operatorname{nn} R 2), 87 \%$ of the aphids molted from nymphs into adults and developed with normal wings, while only $13 \%$ of the aphids were dead as nymphs (Figure $4 B$ ). Aphids treated with a mixture of dsInR1 and dsInR2 were significantly different versus dsGFP, dsInR1, and $\operatorname{ds} \operatorname{InR} 2$ in overall presented phenotypes ( $p=0.000$, respectively) (Table 1$)$. For a separate analysis of phenotypes, the mixture of $\mathrm{d} \operatorname{In} R 1$ and $\mathrm{d} \operatorname{In} R 2$ versus $\mathrm{d} \sin R 1$ or $\mathrm{d} \operatorname{In} R 2$ indicated that the mixture treatment led to more aphid mortality in nymphal stages, and fewer aphids transforming into adults, but no difference in adults with malformed wings compared to the single RNAi of AcInR1 and AcInR2 ( $p=0.712$ or 0.442 , respectively) (Table 1$)$.

A
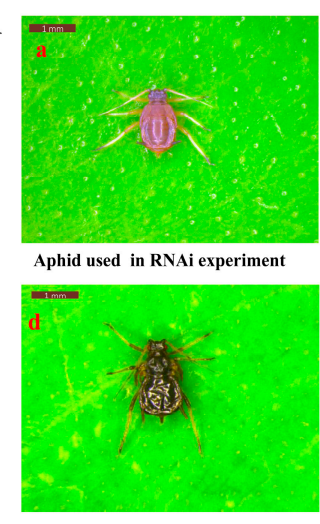

Adult with under-developed wing

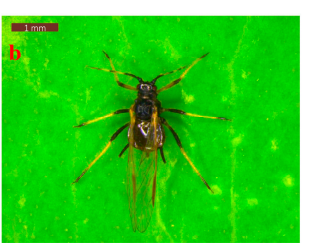

Adult with normal wing

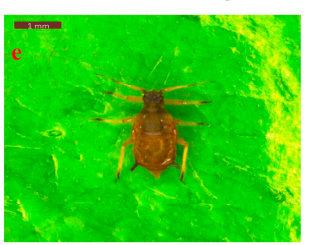

Aphid stuck in nymphal stage

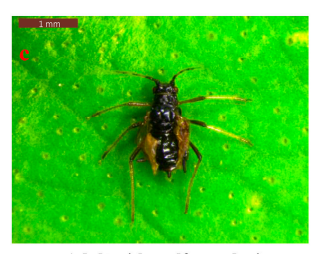

Adult with malformed wing

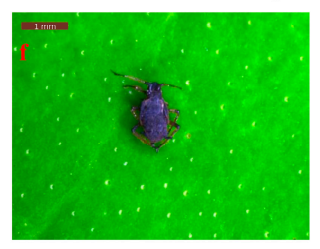

Dead nymphtal aphid

B

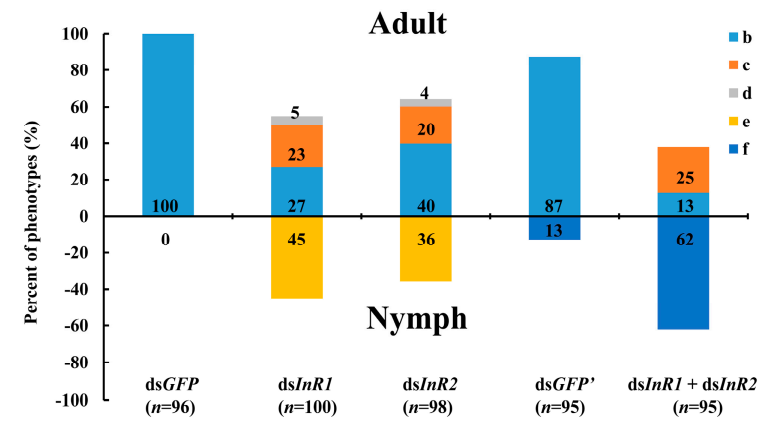

Figure 4. Representative phenotypes of alate A. citricidus after feeding on dsInR1 or dsInR2, and the mixture of dsInR1 and dsInR2 for 72 h. (A) Phenotypes were presented in RNAi experiment; (a) Fourth instar winged-nymphs treated by dsRNA; (b) Adult with normal wing after RNAi; (c) Adult with malformed wing after RNAi; (d) Adult with under-developed wing after RNAi; (e) Aphid stuck in nymphal stage after RNAi; (f) Dead individuals in nymphal stages after RNAi; (B) the rate of presented phenotypes. " $n$ " means the number of aphids in the treatment. dsGFP means the dsRNA concentration of the treatment was $1500 \mathrm{ng} / \mu \mathrm{L}$ and dsGFP' means the dsRNA concentration of the treatment was $3000 \mathrm{ng} / \mu \mathrm{L}$. 
Table 1. Fisher's exact tests of presented phenotypes between different treatments.

\begin{tabular}{|c|c|c|c|c|c|c|}
\hline \multirow[b]{3}{*}{ Comparison } & \multicolumn{6}{|c|}{ Presented Phenotype } \\
\hline & \multirow[b]{2}{*}{$\begin{array}{l}\text { Overall Presented } \\
\text { Phenotypes }\end{array}$} & \multicolumn{3}{|c|}{ Adult Stage } & \multicolumn{2}{|c|}{ Nymph Stage } \\
\hline & & $\begin{array}{l}\text { Normal Wing } \\
\text { (b in Figure 4A) } \\
\text { versus Others }\end{array}$ & $\begin{array}{l}\text { Malformed Wing } \\
\text { (c in Figure 4A) } \\
\text { versus Others }\end{array}$ & $\begin{array}{l}\text { Underdeveloped Wing } \\
\text { (d in Figure 4A) } \\
\text { versus Others }\end{array}$ & $\begin{array}{c}\text { Alive } \\
\text { (e in Figure 4A) } \\
\text { versus Others }\end{array}$ & $\begin{array}{c}\text { Dead } \\
\text { (f in Figure 4A) } \\
\text { versus Others }\end{array}$ \\
\hline dsInR1 versus dsGFP & $* * *(p=0.000)$ & $* * *(p=0.000)$ & $* * *(p=0.000)$ & $*(p=0.026)$ & $* * *(p=0.000)$ & - \\
\hline dsInR2 versus dsGFP & $* * *(p=0.000)$ & $* * *(p=0.000)$ & $* * *(p=0.000)$ & $*(p=0.045)$ & $* * *(p=0.000)$ & - \\
\hline $\mathrm{ds} \operatorname{In} R 1+\mathrm{d} \sin R 2$ versus ds $G F P^{\prime}$ & $* * *(p=0.000)$ & $* * *(p=0.000)$ & $* * *(p=0.000)$ & - & - & $* * *(p=0.000)$ \\
\hline $\mathrm{ds} I n R 1$ versus $\mathrm{ds} \operatorname{In} R 2$ & $\mathrm{NS}(p=0.292)$ & NS $(p=0.056)$ & NS $(p=0.658)$ & NS $(p=0.756)$ & $\mathrm{NS}(p=0.183)$ & 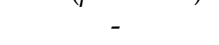 \\
\hline $\mathrm{ds} I n R 1$ versus $\mathrm{d} \operatorname{In} R 1+\mathrm{d} \operatorname{In} R 2$ & $* * *(p=0.000)$ & $*(p=0.012)$ & NS $(p=0.712)$ & $*(p=0.027)$ & $* * *(p=0.000)$ & $* * *(p=0.000)$ \\
\hline $\mathrm{ds} \operatorname{In} R 2$ versus $\mathrm{d} \operatorname{In} R 1+\mathrm{d} \operatorname{In} R 2$ & $* * *(p=0.000)$ & $* * *(p=0.000)$ & NS $(p=0.442)$ & $*(p=0.047)$ & $* * *(p=0.000)$ & $* * *(p=0.000)$ \\
\hline
\end{tabular}

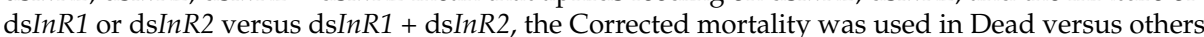




\section{Discussion}

The genomes of three species of aphids, A. pisum [29], D. noxia [34], and M. persicae, were sequenced and the structure of InRs from A. pisum was predicted and characterized [2]. However, the degradation of dsRNA by feeding with an artificial diet or direct injection into aphids has suggested that aphids are insensitive to RNAi treatment [37]. Therefore, the analysis of InRs function in aphids using RNAi has not been carried out. Luan et al. (2013) developed a method to silence whitefly genes involved in ecdysone synthesis and signaling pathways by dsRNA feeding through a plant leaf. This resulted in reduced survival and delayed development of the nymphal stages [38]. Our previous study demonstrated that aphids also cannot molt to adults after silencing of a chitin synthase gene. Aphids have under-developed wings resulting from silencing wing-related genes through plant-stem-mediated dsRNA feeding [36,39].

This report deals with the AcInR1 and AcInR2 insulin receptors from A. citricidus. These receptors showed several important conserved features including a transmembrane segment, an intracellular tyrosine kinase (TyrKc), a furin-like cysteine-rich $(\mathrm{Fu})$ region, followed by three fibronectin type 3 (FN3-1, FN3-2, and FN3-3) domains. These features are salient insulin receptor domains [40,41]. Phylogenic analyses indicated that InR and InR1 may have similar physiological functions and evolutionary relatedness in several insect groups. InR2 separates from the clade of InR1, which indicates that InR2 may play a different role compared to InR1 [6,7]. InR2 seems to be mainly present in insects with polymorphism (aphids, planthoppers, bugs, ants, bees, and dampwood termites). However, at least one non-polymorphic insect, T. castaneum, also has two insulin receptor genes. The relationship between the number of insulin receptors and insect species evolution needs additional work.

The activity of the ISS pathway not only depends on the expression of InR but also on phosphorylation events following activation by the corresponding ligands. The gene expression patterns provide information useful for predicting potential functions. AcInR1 and AcInR2 had different expression patterns both in alate and apterous aphids. AcInR2 had the highest expression level in second instar nymphs and this was higher in apterous aphids than in alate aphids. The second to third instar nymph is the key period for determining the wing morph (apterous or alate) in aphids [24,42]. Our results indicate that $A c I n R 2$ might be involved in wing dimorphism and may play a relatively more important role in apterous aphids. Similar results were found in N. lugens, where NlInR2 was highly expressed in the fifth instar nymph [6] and wing dimorphism (short-wing and long-wing morphs) occurred during the fifth instar nymph to adult stages [43]. AcInR1 had the highest expression levels in alate adults, but no difference among the nymphal stages and no difference in apterous aphids. The wing buds developed slowly in each nymphal instar until the fully formed wings unfolded after adult emergence [44]. Thus, the fourth instar nymph to adult transition was the key period of aphid wing development. Our results indicate that $A c I n R 1$ plays an important role in development (including wing development) from fourth instar nymphs to adults. Similar differences in expression patterns of insulin receptor genes were found in the honey bee, A. mellifera. Both AmInR1 and AmInR2 had the highest expression level in eggs and different expression patterns in queens and workers, indicating that they might be associated with caste determination [18]. In T. castaneum, TcInR1 is expressed at the highest levels in the old adult stage followed by the early pupal stage, whereas TcInR2 is most highly expressed during the larval stages followed by the old adult stage, suggesting that TcInR1 and TcInR2 most likely perform specific functions in larval-pupal development and in reproduction at distinct developmental time points and to different extents [7].

The plant-stem-delivered dsRNA feeding experiment explored the functions of AcInR1 and $A c \operatorname{InR} 2$ and their effects on aphid development during the nymph-adult transition. AcInR1 and AcInR2 appear to be essential for the successful nymph-to-adult development of alate $A$. citricidus. Silencing of AcInR1 and AcInR2 resulted in most aphids being either unable to molt normally to the adult stage, nymphs not molting to the adult stage, or adults with deformed wings. Wing deformities $(24 \%-28 \%)$ were common after silencing of $A c I n R 1$ and/or AcInR2 together with defects in the nymph-adult 
transition. We did not observe other aphid abnormalities following silencing of the insulin receptors. The wing deformities seen in this study may indicate that insulin receptors help to regulate wing development since the deformed aphids successfully transformed from nymphs to adults. However, advanced studies are needed to elucidate how insulin receptors could be involved in regulating wing development. No differences were seen in the rates of all presented phenotypes after dsInR1 and $\mathrm{ds} I n R 2$ treatment. These findings indicate that despite the sequence differences between InR1 and InR2, InR2 shares overlapping functions with InR1 during alate A. citricidus development. In the double-knockdown experiment, aphids fed the ds $I n R 1$ and ds $I n R 2$ mixture experienced high mortality. Silencing of $A c \operatorname{In} R 1$ and $A c \operatorname{InR} 2$ disrupted the development (including wing development) of the aphids during the nymph-adult transition and this might indicate that decreased capability for food intake reduced nutrient transport. Other studies have demonstrated that high expression levels of BdInR, BmInR, and BgInR were induced by starvation of B. dorsalis, B. mori, and B. germanica, respectively $[3,16,45]$. In $T$. castaneum, knockdown of $T c I n R 1$ decreased food intake through the sulfakinin signal pathway in the larval stages [21]. In the present study, both AcInR1 and AcInR2 were involved in the nymph-adult transition and wing development. This suggests that these two insulin receptors might be conserved during aphid development, while they could also play different roles in other aphid processes. Because high mortality occurred in first instar nymphs using the RNAi system, the function of $A \operatorname{In} R 1$ and $A c I n R 2$ in wing dimorphism needs further verification. Genome editing tools such as CRISPR/Cas9 (clustered, regularly interspaced, short palindromic repeat/CRISPR associated) [46] have been used in many insects and this tool will be helpful in exploring the distinct role of AcInR1 and AcInR2 in aphid wing dimorphism and the development of apterous aphids. This study focused on the nymph-adult transition and presented an approach for exploring functions of genes in aphids. More phenotypes will be examined in future work which will evaluate factors such as fecundity, lifespan, and feeding behavior.

\section{Materials and Methods}

\subsection{Insect Culture}

Alate A. citricidus adults were obtained in 2012 from a wild aphid population in a citrus screenhouse at Southwest University, Chongqing, China. Stock colonies were maintained on potted citrus seedlings (Citrus sinensis) in the laboratory at $25 \pm 1{ }^{\circ} \mathrm{C}, 75 \%-80 \%$ relative humidity and $14: 10 \mathrm{~h}$ (Light:Dark) photoperiod. Alate morphs were induced by high-density aphid rearing after transfer to fresh host plants [31,32]. All progeny were produced by parthenogenesis from the stock colony.

\subsection{Total RNA Extraction and cDNA Synthesis}

Total RNA used for gene cloning and expression levels from different developmental stages, wing morphs, and dsRNA treatment were isolated with a TRIzol kit (Invitrogen, Carlsbad, CA, USA) according to manufacturer instructions. RNA was quantified by measuring absorbance at $260 \mathrm{~nm}$ using a Nano Vue UV-Vis spectrophotometer (GE Healthcare Bio-Science, Uppsala, Sweden). The purity of all RNA samples was assessed from the absorbance ratio at OD260/280 and OD260/230. The RNA integrity was then checked by $1 \%$ agarose gel electrophoresis. The genomic DNA was removed by using of DNase I (Promega, Madison, WI, USA). The first strand cDNA was synthesized from 500 ng of DNA-free RNA using a PrimerScript ${ }^{\circledR}$ RT Reagent Kit (Takara, Dalian, China) according to manufacturer instructions. Briefly, the $10 \mu \mathrm{L}$ reaction system consisting of $500 \mathrm{ng}$ RNA, $2 \mu \mathrm{L}$ reverse transcription buffer, 200 pmol random 6 mers, $0.5 \mu \mathrm{L}$ PrimerScript ${ }^{\circledR}$ RT Enzyme Mix I and RNase free $\mathrm{H}_{2} \mathrm{O}$. The reaction conditions included a step of $37^{\circ} \mathrm{C}$ for $15 \mathrm{~min}$ and $85^{\circ} \mathrm{C}$ for $5 \mathrm{~s}$ by using a C1000TM Thermal Cycler (Bio-Rad, Hercules, CA, USA). After the reverse transcription, the synthesized cDNA was stored at $-20^{\circ} \mathrm{C}$ for later use. 


\section{3. cDNA Cloning}

Based on results of the high throughput transcriptome sequencing of A. citricidus (Sequence Read Archive database accession No. SRR2123649) and use of BLASTx against NCBI non-redundant (NR) protein database, we identified two unigene sequences (c13292.graph_c0 and c8883.graph_c0) that were predicted to encode the insulin receptor. The cloning strategy was designed to achieve a full-length confirmation (Table S1, InR1 and InR2). The specific PCR reactions were performed in a C1000TM Thermal Cycler and the PCR amplifications were performed in $25 \mu \mathrm{L}$, containing $1 \mu \mathrm{L}$ cDNA complete, $2.5 \mu \mathrm{L} 10 \times$ PCR buffer ( $\mathrm{Mg}^{2+}$ free), $2 \mu \mathrm{L} 2.5 \mathrm{mM} \mathrm{Mg}^{2+}, 2 \mu \mathrm{L} 2.5 \mathrm{mM}$ dNTP Mix, $15.5 \mu \mathrm{L}$ nuclease-free water, $1 \mu \mathrm{L}$ of each specific primer $(10 \mathrm{mM})$, and $0.25 \mu \mathrm{L} \mathrm{rTaq}{ }^{\mathrm{TM}}$ polymerase (Takara). The PCR reaction was performed as followed: an initial denaturation for $3 \mathrm{~min}$ at $95^{\circ} \mathrm{C}$, followed by $95^{\circ} \mathrm{C}$ for $30 \mathrm{~s}, 55$ to $60^{\circ} \mathrm{C}$ (based on the primer annealing temperatures) for $30 \mathrm{~s}, 72{ }^{\circ} \mathrm{C}$ extension for 1 to $2 \mathrm{~min}$ by 35 cycles and a final extension at $72{ }^{\circ} \mathrm{C}$ for $10 \mathrm{~min}$. The amplified PCR fragments were gel-purified with a Gel Extraction Mini Kit (Takara) and ligated into pGEM-T easy vector (Promega). Recombinant plasmids were sequenced subsequently by an ABI Model 3100 automated sequencer (Invitrogen Life Technologies, Shanghai, China).

\subsection{Phylogenetic Analysis}

The SMART program provided by EMBL (available on: http://smart.embl-heidelberg.de/) was used for the identification of modular domains. The transmembrane helices were analyzed using TMHMM v. 2.0 (available on: http://www.cbs.dtu.dk/services/TMHMM-2.0/). Molecular weights and isoelectric points $(\mathrm{pI})$ of the deduced protein sequences were predicted by the COMPUTE PI/Mw program provided by ExPASy (available on: http://web.expasy.org/compute_pi/). DNAMAN 6.0 (DNAMAN 6.0, Lynnon BioSoft, Vaudreuil, QC, Canada) was used to edit the nucleotide sequences. The full-length amino acid sequences were aligned with ClustalW using MEGA 5.05. The phylogenetic trees were constructed using the maximum likelihood (ML) method with " $p$-distance" as the amino acid substitution model, "pairwise deletion" as the gaps/missing data treatment and 1000 bootstrap replications [47]. The Insulin receptor genes used to generate the tree were from 25 insects and their GenBank IDs were listed in Table S2.

\subsection{Quantitative Reverse Transcription PCR (RT-qPCR)}

To determine the expression profiles of AcInR1 and AcInR2 in different development stages of brown citrus aphid, thirty insects each of first, second, third, fourth instar nymphs, and 30 apterous and alate adults were collected for total RNA isolation. Alate and apterous adults were collected within $48 \mathrm{~h}$ after the final molt. Specific primers used for RT-qPCR analysis were designed by primer 3.0 (available on: http://bioinfo.ut.ee/primer3-0.4.0/). A RT-PCR was performed to check primer specificity before qPCR and the sequences were confirmed as described above. The qPCR was performed on a Mx3000P thermal cycler (Stratagene, La Jolla, CA, USA) with a $10 \mu \mathrm{L}$ reaction mixture containing $0.5 \mu \mathrm{L}$ cDNA completes, $5 \mu \mathrm{L} \mathrm{GoTaq}^{\circledR}$ qPCR Master Mix (Promega), $0.5 \mu \mathrm{L}$ of each specific primer $(0.2 \mathrm{mM})$ and $3.5 \mu \mathrm{L}$ nuclease-free water. PCR amplifications were performed with the following cycling conditions: $95^{\circ} \mathrm{C}$ for $120 \mathrm{~s}$, then 40 cycles of $95^{\circ} \mathrm{C}$ for $30 \mathrm{~s}$ and $60^{\circ} \mathrm{C}$ for $30 \mathrm{~s}$, a final cycle of $60^{\circ} \mathrm{C}$ for $30 \mathrm{~s}$ and $95^{\circ} \mathrm{C}$ for $30 \mathrm{~s}$. A standard curve was established for each primer pair with serial dilutions of cDNA $(1,1 / 5,1 / 25,1 / 125,1 / 625$, and $1 / 3125)$ to determine the amplification efficiencies and $C T$ values. Reference gene, $E F 1 \alpha$, was used to normalize the expression of genes [48] by qBase [49].

\subsection{RNAi}

RNAi was applied to explore the potential biological functions of AcInR1 and AcInR2 in A. citricidus. The primers used to synthesize dsRNA are listed in Supplementary Table S1. The TranscriptAid T7 High Yield Transcription Kit (Thermo Scientific, Wilmington, DE, USA) was using for the dsRNA synthesis. The size of the products was confirmed by electrophoresis on a $1 \%$ 
agarose gel and the sequences were confirmed as described above. The dsRNA concentration was $1500 \mathrm{ng} / \mu \mathrm{L}$ for single RNAi treatment and dsGFP was used as a control in the same concentration. In the co-silencing of two insulin receptors, $\operatorname{ds} \operatorname{In} R 1$ and ds $\operatorname{In} R 2$ were fed simultaneously as a mixture at a 1:1 ratio, each dsRNA concentration was $3000 \mathrm{ng} / \mu \mathrm{L}$ and dsGFP concentration was $3000 \mathrm{ng} / \mu \mathrm{L}$.

A RNAi method to silence gene expression level by dsRNA feeding through a citrus leaf was used based on a previous study [36]. Briefly, an 8-cm-long citrus stem with a fresh leaf was detached from the citrus seeding and inserted into a $250 \mu \mathrm{L}$ PCR tube containing $200 \mu \mathrm{L}$ dsRNA. Then the tube containing the dsRNA and the leaf were transferred into a $50 \mathrm{~mL}$ plastic tube. Twenty-five fourth-instar nymphs were released onto the leaf and representative phenotypes were observed after dsRNA treatment for $72 \mathrm{~h}$.

Four biological replicates were performed for each treatment. Photos were taken using a Leica M165C microscope (Leica Microsystems, Wetzlar, Germany). To assess the down-regulation of AcInR1 and AcInR2 by dsRNA feeding, all surviving aphids after feeding on dsRNA for $72 \mathrm{~h}$ were pooled for RNA extraction to examine gene expression level and qPCR was performed as described above.

\subsection{Statistical Analysis}

The relative expression levels of $A \operatorname{In} R 1$ and $A \operatorname{In} R 2$ in different development stages were analyzed using one-way analysis of variance (ANOVA) followed by Tukey's honestly significant difference (HSD) multiple comparison test. The level of significance was set at $p<0.05$. The expression levels of AcInR1 and AcInR2 between dsRNA-treated and control were compared by using a two-tailed Student's $t$-test at the significance levels of ${ }^{*} p<0.05$ and ${ }^{* *} p<0.01$. The percentage of presented phenotypes among treatments were analyzed using a two-tailed Fisher's exact test with $2 \times n$ contingency tables $\left({ }^{*} p<0.05,{ }^{* *} p<0.01\right.$, and $\left.{ }^{* * *} p<0.01\right)$. All statistical analysis was carried out using SPSS version 20.0 (IBM, Armonk, NY, USA).

\section{Conclusions}

We identified two insulin receptor genes, AcInR1 and AcInR2, in the brown citrus aphid, A. citricidus. The gene expression patterns indicated that they play important roles in the nymph-to-adult transition. RNAi results showed that AcInR1 and AcInR2 are essential genes for A. citricidus development and have overlapping functions, even though their sequences are significantly different. The results provide a foundation for the advanced study of insulin receptors in aphids. They also provide a theoretical basis, using RNAi technology, for controlling the dispersal of this pest.

Supplementary Materials: Supplementary materials can be found at www.mdpi.com/1422-0067/18/2/357/s1.

Acknowledgments: This research was supported in part by the Special Fund for Agro-scientific Research in the Public Interest (201203038), the earmarked fund for Modern Agro-industry (Citrus) Technology Research System of China (CARS-27), the Innovation Fund for Graduate Students of Chongqing (CYB16073), and the Foundation Project of Southwest University (SWU114049).

Author Contributions: Bi-Yue Ding, Feng Shang, Jin-Zhi Niu and Jin-Jun Wang conceived and designed the experiments; Bi-Yue Ding, Feng Shang, Qiang Zhang and Ying Xiong performed the experiments; Bi-Yue Ding, Feng Shang, Qun Yang, Jin-Zhi Niu and Jin-Jun Wang analyzed the data; Bi-Yue Ding, Feng Shang, Jin-Zhi Niu, Guy Smagghe and Jin-Jun Wang wrote the paper.

Conflicts of Interest: The authors declare no conflict of interest.

\section{References}

1. Wu, Y.B.; Yang, W.J.; Xie, Y.F.; Xu, K.K.; Tian, Y.; Yuan, G.R.; Wang, J.J. Molecular characterization and functional analysis of BdFoxO gene in the oriental fruit fly, Bactrocera dorsalis (Diptera: Tephritidae). Gene 2015, 578, 219-224. [CrossRef] [PubMed]

2. Guo, S.S.; Zhang, M.; Liu, T.X. Insulin-related peptide 5 is involved in regulating embryo development and biochemical composition in pea aphid with wing polyphenism. Front. Physiol. 2016, 7, 31. [CrossRef] [PubMed] 
3. Xu, K.K.; Yang, W.J.; Tian, Y.; Wu, Y.B.; Wang, J.J. Insulin signaling pathway in the oriental fruit fly: The role of insulin receptor substrate in ovarian development. Gen. Comp. Endocr. 2014, 216, 125-133. [CrossRef] [PubMed]

4. Williams, K.D.; Busto, M.; Suster, M.L.; So, A.K.C.; Ben-Shahar, Y.; Leevers, S.J.; Sokolowski, M.B. Natural variation in Drosophila melanogaster diapause due to the insulin-regulated PI3-kinase. Proc. Natl. Acad. Sci. USA 2006, 103, 15911-15915. [CrossRef] [PubMed]

5. Sim, C.; Denlinger, D.L. Insulin signaling and FOXO regulate the overwintering diapause of the mosquito Culex pipiens. Proc. Natl. Acad. Sci. USA 2008, 105, 6777-6781. [CrossRef] [PubMed]

6. Xu, H.J.; Xue, J.; Lu, B.; Zhang, X.C.; Zhuo, J.C.; He, S.F.; Ma, X.F.; Jiang, Y.Q.; Fan, H.W.; Xu, J.Y.; et al. Two insulin receptors determine alternative wing morphs in planthoppers. Nature 2015, 519, 464-467. [CrossRef] [PubMed]

7. Sang, M.; Li, C.j.; Wu, W.; Li, B. Identification and evolution of two insulin receptor genes involved in Tribolium castaneum development and reproduction. Gene 2016, 585, 196-204. [CrossRef] [PubMed]

8. Nässel, D.R.; Broeck, J.V. Insulin/IGF signaling in Drosophila and other insects: Factors that regulate production, release and post-release action of the insulin-like peptides. Cell. Mol. Life Sci. 2016, 73, 271-290. [CrossRef] [PubMed]

9. Cantley, L.C. The phosphoinositide 3-kinase pathway. Science 2002, 296, 1655-1657. [CrossRef] [PubMed]

10. Brogiolo, W.; Stocker, H.; Ikeya, T.; Rintelen, F.; Fernandez, R.; Hafen, E. An evolutionarily conserved function of the Drosophila insulin receptor and insulin-like peptides in growth control. Curr. Biol. 2001, 11, 213-221. [CrossRef]

11. Oldham, S.; Hafen, E. Insulin/IGF and target of rapamycin signaling: A TOR de force in growth control. Trends Cell Biol. 2003, 13, 79-85. [CrossRef]

12. Wu, Q.; Brown, M.R. Signaling and function of insulin-like peptides in insects. Annu. Rev. Entomol. 2006, 51, 1-24. [CrossRef] [PubMed]

13. Garofalo, R.S. Genetic analysis of insulin signaling in Drosophila. Trends Endocrinol. Metab. 2002, 13, $156-162$. [CrossRef]

14. Graf, R.; Neuenschwander, S.; Brown, M.; Ackermann, U. Insulin-mediated secretion of ecdysteroids from mosquito ovaries and molecular cloning of the insulin receptor homologue from ovaries of bloodfed Aedes aegypti. Insect Mol. Biol. 1997, 6, 151-163. [CrossRef] [PubMed]

15. Fullbright, G.; Lacy, E.R.; Büllesbach, E.E. The prothoracicotropic hormone bombyxin has specific receptors on insect ovarian cells. Eur. J. Biochem. 1997, 245, 774-780. [CrossRef] [PubMed]

16. Abrisqueta, M.; Sueren Castillo, S.; Maestro, J.L. Insulin receptor-mediated nutritional signalling regulates juvenile hormone biosynthesis and vitellogenin production in the German cockroach. Insect Biochem. Mol. Biol. 2014, 49, 14-23. [CrossRef] [PubMed]

17. Lavine, L.C.; Hahn, L.L.; Warren, I.A.; Garczynski, S.F.; Dworkin, I.; Emlen, D.J. Cloning and characterization of an mrna encoding an insulin receptor from the horned scarab beetle Onthophagus nigriventris (Coleoptera: Scarabaeidae). Arch. Insect Biochem. 2013, 82, 43-57. [CrossRef] [PubMed]

18. De Azevedo, S.V.; Hartfelder, K. The insulin signaling pathway in honey bee (Apis mellifera) caste development-Differential expression of insulin-like peptides and insulin receptors in queen and worker larvae. J. Insect Physiol. 2008, 54, 1064-1071. [CrossRef] [PubMed]

19. Lu, H.L.; Pietrantonio, P.V. Insect insulin receptors: Insights from sequence and caste expression analyses of two cloned hymenopteran insulin receptor cdnas from the fire ant. Insect Mol. Biol. 2011, 20, 637-649. [CrossRef] [PubMed]

20. Chen, C.; Jack, J.; Garofalo, R.S. The Drosophila insulin receptor is required for normal growth. Endocrinology 1996, 137, 846-856. [PubMed]

21. Lin, X.; Yu, N.; Smagghe, G. Insulin receptor regulates food intake through sulfakinin signaling in the red flour beetle, Tribolium castaneum. Peptides 2016, 80, 89-95. [CrossRef] [PubMed]

22. Zhang, Z.; Teng, X.L.; Chen, M.H.; Li, F. Orthologs of human disease associated genes and RNAi analysis of silencing insulin receptor gene in Bombyx mori. Int. J. Mol. Sci. 2014, 15, 18102-18116. [CrossRef] [PubMed]

23. Tatar, M.; Kopelman, A.; Epstein, D.; Tu, M.P.; Yin, C.M.; Garofalo, R.S. A mutant Drosophila insulin receptor homolog that extends life-span and impairs neuroendocrine function. Science 2001, 292, 107-110. [CrossRef] [PubMed] 
24. Braendle, C.; Davis, G.K.; Brisson, J.A.; Stern, D.L. Wing dimorphism in aphids. Heredity 2006, 97, $192-199$. [CrossRef] [PubMed]

25. Srinivasan, D.G.; Brisson, J.A. Aphids: A model for polyphenism and epigenetics. Genet. Res. Int. 2012, 2012, 431531. [CrossRef] [PubMed]

26. Ishikawa, A.; Hongo, S.; Miura, T. Morphological and histological examination of polyphenic wing formation in the pea aphid Acyrthosiphon pisum (Hemiptera, hexapoda). Zoomorphology 2008, 127, 121-133. [CrossRef]

27. Ishikawa, A.; Gotoh, H.; Abe, T.; Miura, T. Juvenile hormone titer and wing-morph differentiation in the vetch aphid Megoura crassicauda. J. Insect Physiol. 2013, 59, 444-449. [CrossRef] [PubMed]

28. Ogawa, K.; Miura, T. Aphid polyphenisms: Trans-generational developmental regulation through viviparity. Front. Physiol. 2014, 5, 1. [CrossRef] [PubMed]

29. Consortium, I.A.G. Genome sequence of the pea aphid Acyrthosiphon pisum. PLoS Biol. 2010, 8, e1000313.

30. Moreno, P.; Ambr, O.S.; Albiach Martí, M.R.; Guerri, J.; Pena, L. Citrus tristeza virus: A pathogen that changed the course of the citrus industry. Mol. Plant. Pathol. 2008, 9, 251-268. [CrossRef] [PubMed]

31. Hunter, W.B.; Dang, P.M.; Bausher, M.; Chaparro, J.X.; McKendree, W.; Shatters, R.G., Jr.; McKenzie, C.L.; Sinisterra, X.H. Aphid biology: Expressed genes from alate Toxoptera citricida, the brown citrus aphid. J. Insect Sci. 2003, 3, 23. [CrossRef] [PubMed]

32. Michaud, J.P. Colony density and wing development in Toxoptera citricida (Homoptera, aphididae). Environ. Entomol. 2001, 30, 1047-1051. [CrossRef]

33. Halbert, S.E.; Brown, L.G. Toxoptera Citricida (Kirkaldy), Brown Citrus Aphid-Identification, Biology, And Management Strategies. In Entomology Circular; Florida Department of Agriculture and Consumer Services-Division of Plant Industry: Tallahassee, FL, USA, 1998.

34. Nicholson, S.J.; Nickerson, M.L.; Dean, M.; Song, Y.; Hoyt, P.R.; Rhee, H.; Kim, C.; Puterka, G.J. The genome of Diuraphis noxia, a global aphid pest of small grains. BMC Genom. 2015, 16, 429. [CrossRef] [PubMed]

35. Brisson, J.A.; Ishikawa, A.; Miura, T. Wing development genes of the pea aphid and differential gene expression between winged and unwinged morphs. Insect Mol. Biol. 2010, 19, 63-73. [CrossRef] [PubMed]

36. Shang, F.; Xiong, Y.; Xia, W.K.; Wei, D.D.; Wei, D.; Wang, J.J. Identification, characterization and functional analysis of a chitin synthase gene in the brown citrus aphid, Toxoptera citricida (Hemiptera, aphididae). Insect Mol. Biol. 2016, 25, 422-430. [CrossRef] [PubMed]

37. Christiaens, O.; Swevers, L.; Smagghe, G. DsRNA degradation in the pea aphid (Acyrthosiphon pisum) associated with lack of response in RNAi feeding and injection assay. Peptides 2014, 53, 307-314. [CrossRef] [PubMed]

38. Luan, J.B.; Ghanim, M.; Liu, S.S.; Czosnek, H. Silencing the ecdysone synthesis and signaling pathway genes disrupts nymphal development in the whitefly. Insect Biochem. Mol. Biol. 2013, 43, 740-746. [CrossRef] [PubMed]

39. Shang, F.; Ding, B.Y.; Xiong, Y.; Dou, W.; Wei, D.; Jiang, H.B.; Wei, D.D.; Wang, J.J. Differential expression of genes in the alate and apterous morphs of the brown citrus aphid, Toxoptera citricida. Sci. Rep. 2016, 6, 32099. [CrossRef] [PubMed]

40. De Meyts, P.; Whittaker, J. Structural biology of insulin and IGF1 receptors: Implications for drug design. Nat. Rev. Drug Discov. 2002, 1, 769-783. [CrossRef] [PubMed]

41. De Meyts, P. Insulin and its receptor: Structure, function and evolution. Bioessays 2004, 26, 1351-1362. [CrossRef] [PubMed]

42. Ganassi, S.; Signa, G.; Mola, L. Development of the wing buds in Megoura viciae: A morphological study. Bull. Insectol. 2005, 58, 101-105.

43. Bertuso, A.G.; Morooka, S.; Tojo, S. Sensitive periods for wing development and precocious metamorphosis after precocene treatment of the brown planthopper, Nilaparvata lugens. J. Insect Physiol. 2002, 48, 221-229. [CrossRef]

44. Müller, C.B.; Williams, I.S.; Hardie, J. The role of nutrition, crowding and interspecific interactions in the development of winged aphids. Ecol. Entomol. 2001, 26, 330-340. [CrossRef]

45. Liu, Y.; Zhou, S.; Ma, L.; Tian, L.; Wang, S.; Sheng, Z.T.; Jiang, R.J.; Bendena, W.G.; Li, S. Transcriptional regulation of the insulin signaling pathway genes by starvation and 20-hydroxyecdysone in the Bombyx fat body. J. Insect Physiol. 2010, 56, 1436-1444. [CrossRef] [PubMed]

46. Tanning, C.N.T.; Eynde, B.V.; Yu, N.; Ma, S.; Smagghe, G. CRISPR/Cas9 in insect: Applications, best practices and biosafety concerns. J. Insect Physiol. 2017, 98, 245-257. [CrossRef] [PubMed] 
47. Tamura, K.; Peterson, D.; Peterson, N.; Stecher, G.; Nei, M.; Kumar, S. MEGA5: Molecular evolutionary genetics analysis using maximum likelihood, evolutionary distance, and maximum parsimony methods. Mol. Biol. Evol. 2011, 28, 2731-2739. [CrossRef] [PubMed]

48. Shang, F.; Wei, D.D.; Jiang, X.Z.; Wei, D.; Shen, G.M.; Feng, Y.C.; Li, T.; Wang, J.J. Reference gene validation for quantitative PCR under various biotic and abiotic stress conditions in Toxoptera citricida (Hemiptera, aphididae). J. Econ. Entomol. 2015, 108, 2040-2047. [CrossRef] [PubMed]

49. Hellemans, J.; Mortier, G.; de Paepe, A.; Speleman, F.; Vandesompele, J. Qbase relative quantification framework and software for management and automated analysis of real-time quantitative PCR data. Genome Biol. 2007, 8, 19. [CrossRef] [PubMed]

(C) 2017 by the authors. Licensee MDPI, Basel, Switzerland. This article is an open access article distributed under the terms and conditions of the Creative Commons Attribution (CC BY) license (http://creativecommons.org/licenses/by/4.0/). 